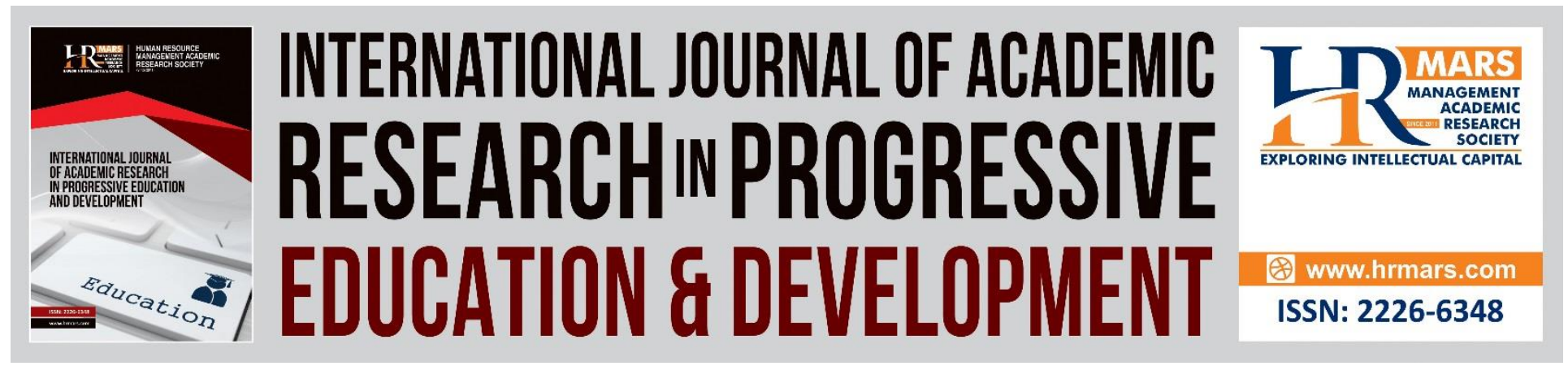

\title{
The Analysis of Implementation and Scoring for KSSM Oral Assessment Among the Lower Secondary Teachers
}

Rozita Radhiah Said, Halimah Jamil

To Link this Article: http://dx.doi.org/10.6007/IJARPED/v10-i2/10497

DOI:10.6007/IJARPED/v10-i2/10497

Received: 06 April 2021, Revised: 10 May 2021, Accepted: 24 May 2021

Published Online: 22 June 2021

In-Text Citation: (Said \& Jamil, 2021)

To Cite this Article: Said, R. R., \& Jamil, H. (2021). The Analysis of Implementation and Scoring for KSSM Oral Assessment Among the Lower Secondary Teachers. International Journal of Academic Research in

Progressive Education and Development, 10(2), 964-982.

Copyright: (C) 2021 The Author(s)

Published by Human Resource Management Academic Research Society (www.hrmars.com)

This article is published under the Creative Commons Attribution (CC BY 4.0) license. Anyone may reproduce, distribute, translate and create derivative works of this article (for both commercial and non-commercial purposes), subject to full attribution to the original publication and authors. The full terms of this license may be seen at: http://creativecommons.org/licences/by/4.0/legalcode

Vol. 10(2) 2021, Pg. 964 - 982

http://hrmars.com/index.php/pages/detail/IJARPED

JOURNAL HOMEPAGE

Full Terms \& Conditions of access and use can be found at http://hrmars.com/index.php/pages/detail/publication-ethics 


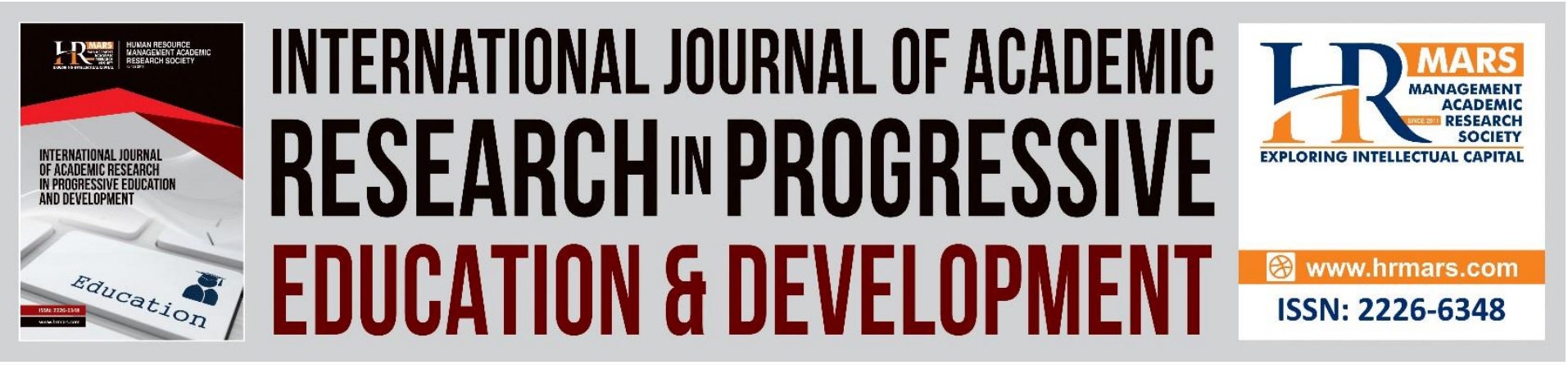

\title{
The Analysis of Implementation and Scoring for KSSM Oral Assessment Among the Lower Secondary Teachers
}

\author{
${ }^{1}$ Rozita Radhiah Said, ${ }^{2}$ Halimah Jamil \\ ${ }^{1}$ Department of Language and Humanities Education, Faculty of Educational Studies, Universiti \\ Putra Malaysia, 43400 Serdang, Malaysia, ${ }^{2}$ Sekolah Menengah Rantau, Negeri Sembilan, \\ Malaysia
}

\begin{abstract}
The Standards-Based Curriculum for Secondary School (KSSM) was first implemented in Malaysia in 2012 by applying an assessment system integrated with the teaching and learning process (T\&L) to replace the previous education system that was more examination-oriented. The Curriculum and Assessment Standard Document (DSKP) for the Malay Language subject was introduced in April 2016 and implemented by stages from 2017 until now. Thus, after three years, this study attempts to analyse the implementation and scoring procedures of oral assessment integrated with teaching and learning in the classroom among the seven lower secondary school teachers from a district in Negeri Sembilan. Two participants were selected to represent each school in different categories which are Sekolah Menengah Kebangsaan (SMK), Sekolah Agama Bantuan Kerajaan (SABK) and Sekolah Berprestasi Tinggi (SBP). Qualitative research with a case study design has been conducted on seven Malay Language teachers between 26 to 52 years old. They were selected through purposive sampling. The research data were collected by triangulation, through the interview method, observation on the implementation of oral assessment for teaching and learning $(T \& L)$ in the classroom, and document analysis. The collected data were analysed using the ATLAS.ti software version 8 . The main findings of the study showed that all participants successfully implemented the assessment based on DSKP. However, the oral scoring procedure should still be emphasized and monitored because three out of seven Malay Language teachers did not enforce it using a proper process. In general, this study found that the teachers successfully integrated the theory of the function, the role of classroom assessment, and the steps outlined by the Ministry of Education (MoE), starting from the planning procedure, selecting methods, implementing, recording, follow-up action, and reporting the assessment. Recommendations for future studies related to scoring consistency, rubric appropriateness, reporting, and assessment quality monitoring need to be enforced in
\end{abstract}


every assessment aspect to make sure it is in parallel which results are complementary and high accountability of the assessment.

Keywords: Implementation Procedures, Assessment, Oral Scoring, Oral Skills Standards, KSSM

\section{Introduction}

The basis for the development of the Standards-Based Curriculum for Secondary School (KSSM) is to ensure that the student's profession in the language relies on the communication skills to be able for them to compete at the international level. This matter has been outlined in the second shift of Malaysia Education Blueprint (MEB) 2013-2025. According to the new curriculum of KSSM, the standard of the Curriculum and Assessment Standard Document (DSKP) has become a basic reference for Malay language teachers to ensure each student excelled in the Content Standards (SK), Learning Standards (SP), and Performance Standards (SPi). The guidebook of Classroom Assessment (PPPBD) also has become an official reference for the teachers to refer throughout the assessment from the initial stage to the final stage. The results of this study are expected to give an implication for the schools and the teachers, especially the Malay language teachers, to make the DSKP and the PPPBD as key hold while conducting an oral assessment in the classroom.

\section{Problem Statement}

The transformation of the national education system to the School-Based Assessment (SBA) has impacted its implementation among the teachers with new demands in the assessment system. In applying formative assessment, the study found that the teachers have low competency and knowledge since the period of the SBA course was so short, causing them to develop unclear information and did not understand how the assessment should be implemented. Besides, the teachers who attended did not focus, and the stakeholders only indicate how to write the Lesson Plan (LP) instead of guiding the teachers on assessing the students (Abu Naim, \& Talib, 2014). In fact, there is a teacher who received information related to SBA through the Head Coach (JU) in the In-Service Training (LADAP) and causing the problems to occur due to the JU that does not fully understand the course content while presented to the teachers. The allocation of short course duration causing the teachers' knowledge on actual implementation and scoring method of assessment to be unclear (Abu Naim \& Talib, 2014; Khamidi, 2015). Adequate readiness and knowledge related to assessment should be inculcated in a teacher before preparing the instrument, determining the student's level of mastery, and interpreting the student's assessment score (Lim et al., 2014). The curriculum changes are a complex and challenging process that requires detailed planning, sufficient period, funding, support, and opportunities for teachers as implementers of the new curriculum. The changes would take three to five years to implement the difficult innovations and take another year to evaluate such changes (Mclaughlin, 1982). The implication will affect the student's learning performance. Besides, giving different and non-transparent (bias) scores will show a significant scoring difference among the students (Suseela \& Sim, 2010), and the implementation of formative assessment is considered to be so complex (Vingsle, 2014). A quantitative study conducted by Arsaythamby, Hariharan, and Ruzlan (2015) and Tan (2010) found that teachers face the challenge of handling assessment scoring in the classroom, giving the students scores unfairly and illegally. This happens due the teachers 
Vol. 10, No. 2, 2021, E-ISSN: 2226-6348 @ 2021 HRMARS

were less prepared and have a low level of knowledge related to it because they are not clear on how to handle an assessment that involves assessment instruments, rubrics, assessment guidelines, and the procedures that should be done during the evaluation. The effect of having insufficient knowledge in handling the assessment causes some teachers to completely ignore it by not implementing the assessment as directed by the ministry (Tan, 2010).

\section{Research Objective}

1. Analyse the implementation steps of oral assessment in the classroom.

2. Formulate the scoring method of student's Proficiency Level during the oral assessment.

\section{Research Questions}

1. How to run the implementation of oral assessments for the Malay language?

a) Does the implementation of teachers' oral assessment comply with PPP?

2. How do the teachers giving scoring on the students' Proficiency Levels in oral assessments?

\section{Literature Review}

Evaluation, measurement, evaluation, and assessment are explicit tools or procedures for measuring individual behaviour (Bachman, 1990; Cronbach, 1990), especially determining a student's mastery level (Arsaythamby \& Rosna, 2016). Meanwhile, Bachman (1990) stated that this is focused not only on language testing on students but also on language teaching, language learning, and language research domains. This situation will allow the teachers and students to make self-reflection and plan improvements in teaching and learning. It even provides encouragement and intrinsic motivation in the students to prepare for their test at the appointed time. The assessment and evaluation are a data collection process that requires the teachers to analyse, reflect, and make recommendations on the data received from the students (Baranovskaya \& Shaforostova, 2017) to see whether the objectives or goals of teaching and learning are achieved or otherwise. Their study also emphasizes that the implementation of reflection and continuous learning development is a determinant of success for an assessment conducted by the teachers. Arsaythamby \& Rosna (2016), Assessment Reform Group (1999) define the assessment as the diversity of information obtained throughout the learning process inside or outside the classroom as evidence to enhance student learning by using various strategies in the social dimension. The assessment aims to determine the level of learning ability of a student thoroughly without comparing the achievement of other students. The assessment is a classroom activity carried out in various ways which involve an interaction between teachers and students. For example, when the teacher makes observations and analyses the student assignments (homework, tests, essays, and discussion of an issue in the classroom). All assessment activities involving teachers and students are considered information or data that can help improve the quality of T\&L of teachers and students. The assessment practices also allow the teachers and students to review and reflect on the assessment data obtained. Assessment integrated with T\&L involves peer assessment and self-assessment help in boost the student's confidence that their learning achievement can be improved towards a better performance (Ekua, 2016; Broadfoot et al., 1999). 
In the context of Malaysia's education, SBA has been outlined as part of the Malaysia Education Blueprint 2013-2025 (MEB), where the assessment must be in line with the international benchmarks to produce knowledgeable and skilled students to achieve success in the 21st century. Aligned with the content in Chapter 4-Student Learning of Malaysia Education Blueprint 2013-2025 (PPPM), it aims to test the Higher Order Thinking Skills (HOTS) using the SBA standard reference. The assessment implemented in Malaysia is obtaining information from the students based on what the students know, can do, and can practice. Through this process, the teacher plays his role to make decisions professionally as a product of the educational program (student performance).

The formative assessments that take place throughout the year have clear goals and planned by the teachers based on the Curriculum and Assessment Standard Document (DSKP), which contains the Learning Standards (SP), Content Standards (SK), and Performance Standards (SPi) to determine the student's mastery level for each subject to ensure the T\&L implemented effectively. The concept of formative assessment is also applicable to Malay Language subjects for lower secondary students. The teachers will decide by looking at the student's performance whether they should be allowed to improve their learning or continue to the next level of learning (MoE, 2014). For example, the implementation of assessment and evaluation by English teachers helps them acquire systematic information and contribute to the teacher's understanding of the weaknesses and strengths of their student learning development (Baranovskaya \& Shaforostova, 2017). The student's learning development information can improve the teacher's teaching methods for further teaching sessions.

\section{Classroom Assessment (PPPBD)}

At the end of 2016, the term PPPBD is used to replace School Assessment (PS) as a practice on the teacher's evaluation of student learning development. The full instructions for implementation of PPPBD are stated in the Press Release/Release Letter Ref: KPM.600-5/1/5 Vol.3 (6) dated 23 November 2017. At the same time, the Curriculum Development Division (BPK), Education Ministry (MoE) has prepared the Classroom Assessment Implementation Guidebook 2018 as a reference for the teachers to implement the PPPBD more effectively. The formative of PPPBD will be evaluated continuously to help the teachers obtain information on the development and achievement of the student's learning from time to time. The teachers play an important role as administrators, planners, implementers, stuff builders, examiners, record, and report to determine the student's level of mastery for the subjects taught based on DSKP. The assessment process takes place formally and informally, which aims for the teacher to determine the actual level of mastery of the student. The assessment occurs partially during the T\&L in formative assessment or Assessment from Learning ( $A f L)$. It is given the main emphasis to improve the level of student learning while building the potential of students as a whole ( $N a$ 'imah, 2011). At the same time, the summative assessment will be implemented after the end of the learning unit, terms, semester, or year. PPPBD will be implemented by the teacher for every subject continuously throughout the year during the T\&L process in the classroom based on the Curriculum and Assessment Standard Document (DSKP). The DSKP provided for the teachers contains the Performance Standards, Content Standards, and Learning Standards for 
each subject. PPPBD includes formative and summative assessments. Formative assessment practices the concepts of Assessment as Learning ( $A a L)$ and Assessment for Learning (AfL) aimed at assessing the student's learning development implemented in tandem with T\&L. In contrast, summative assessment practices the concept of Assessment of Learning, which is a monthly test and a mid-year or end-of-year examination (LPM, 2011). That means the PPPBD has various forms of authentic and contextual assessment that provide opportunities for teachers as assessors to measure the student's mastery lever in learning for each of the subjects taught. In the context of this study, PPPBD is a guide for the teachers to plan and select the assessment methods according to the development of student learning based on the selected SK and SP.

\section{Methodology \\ Research Design}

This research is a qualitative study that uses a case study design, which is a multi-location case (Merriam, 2009). This case study chooses field research consisting of three data collection methods: interviews, observations, and document analysis for qualitative data. The field research studies conducted in multi-location involved seven participants selected using a purposive sampling method, which is representative from every level of teaching experience. Also, it is based on the characteristics of the subject with expertise, can represent, ready to participate and easy to contact, provide mature and accurate data, give a lot of information and precise perspective of the things to be studied. 
Table I: The Research Participants

\begin{tabular}{|c|c|c|c|c|c|c|c|}
\hline 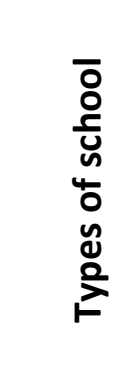 & 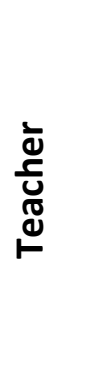 & 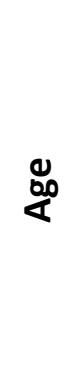 & 这 & 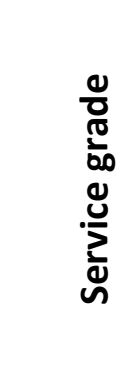 & $\frac{\text { 을 }}{\stackrel{0}{0}}$ & 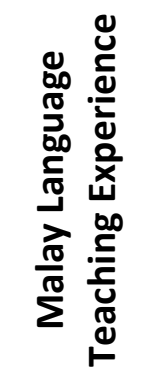 & 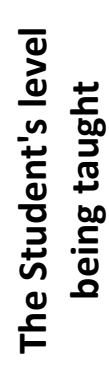 \\
\hline \multirow[t]{2}{*}{ SMK } & PK01 & 52 & Female & DG 48 & $\begin{array}{l}\text { Bachelor of Linguistics, } \\
\text { UKM/Master of Educational } \\
\text { Administration, UPM }\end{array}$ & $\begin{array}{c}28 \\
\text { years }\end{array}$ & 1 \\
\hline & PK02 & 54 & Female & DG 44 & $\begin{array}{c}\text { Bachelor of Malay language } \\
\text { \& Literature, UKM }\end{array}$ & $\begin{array}{c}27 \\
\text { years }\end{array}$ & 1 \\
\hline \multirow{2}{*}{ SABK } & PK03 & 42 & Female & DG 29 & $\begin{array}{c}\text { Malaysian Diploma } \\
\text { inTeaching, IPG BM Campus }\end{array}$ & 9 years & 1 \\
\hline & PK04 & 33 & Female & DG 29 & $\begin{array}{c}\text { Malaysian Diploma } \\
\text { inTeaching, IPG BM Campus }\end{array}$ & $\begin{array}{c}10 \\
\text { years }\end{array}$ & 2 \\
\hline \multirow{3}{*}{ SBP } & PK05 & 28 & Female & DG 41 & $\begin{array}{c}\text { Bachelor of Education } \\
\text { PBMP, UPM }\end{array}$ & 3 years & 2 \\
\hline & & & & & Bachelor of Education & & \\
\hline & PK06 & 32 & Female & DG 41 & $\begin{array}{l}\text { PBMP, UPM / Master of } \\
\text { Malay Language, UPM }\end{array}$ & 9 years & 1 \\
\hline SMKA & PK07 & 26 & Female & DG 41 & $\begin{array}{c}\text { Bachelor of Education } \\
\text { PBMP, UPM }\end{array}$ & 1 years & 1 \\
\hline
\end{tabular}

\section{Research's Instrument}

This was carried out through field research using three methods of data collection, which are semi-structured interviews (See Table III - If necessary, based on the observation results), structured observation (See Table IV), and structured document analysis (See Table V) which will ultimately produce qualitative data. The field research was conducted for eight months.

\section{Validity and Reliability of Information}

To ensure the reliability of this study, several approaches have been used which are prioritize ethical issues by obtaining permission to conduct the study from the relevant parties, keeping the identity of the participants and the location confidential, explain the assumptions and justifications for the use of selected theories, develop a complete and comprehensive data file Rozita Radhiah Said and Abdul Rasid Jamian 56 on participants, prepare an audit network and the detail list of study methods, data analysis procedures and report writing process (see Table II). 
INTERNATIONAL JOURNAL OF ACADEMIC RESEARCH IN PROGRESSIVE EDUCATION AND DEVELOPMENT

Vol. 10, No. 2, 2021, E-ISSN: 2226-6348 @ 2021 HRMARS

Table II: Strategies to Determine the Validity and Reliability

\begin{tabular}{|c|c|c|}
\hline Type of assessment & Strategy & Level of research \\
\hline Construct Validity & $\begin{array}{l}\text { Triangulation: Through the data } \\
\text { collection method; interviewing, observation, } \\
\text { and document analysis. }\end{array}$ & $\begin{array}{l}\text { - } \text { Research design } \\
\text { - Collect } \\
\text { information }\end{array}$ \\
\hline $\begin{array}{l}\text { Internal } \\
\text { Validity }\end{array}$ & $\begin{array}{l}\text { - Information review process with the } \\
\text { participants } \\
\text { - Make long-term observations }\end{array}$ & $\begin{array}{l}\text { Data } \\
\text { collection }\end{array}$ \\
\hline Trustworthiness & $\begin{array}{l}\text { - Explain the theory } \\
\text { - Prioritize the ethical issues } \\
\text { - Develop complete data for each of the } \\
\text { participants } \\
\text { - Provide an audit network }\end{array}$ & $\begin{array}{l}\text { - } \text { Research design } \\
\text { - Collect } \\
\text { information } \\
\text { - Writing report }\end{array}$ \\
\hline
\end{tabular}

\section{Research Findings}

Objective 1

Analyse the implementation steps of oral assessment in the classroom.

There are five steps to implement the oral assessment in the classroom based on the PPPBD as in the theme of Table III. 
Vol. 10, No. 2, 2021, E-ISSN: 2226-6348 @ 2021 HRMARS

Table III: The Interpretation of Data Interview for the Implementation Steps of Oral Assessment

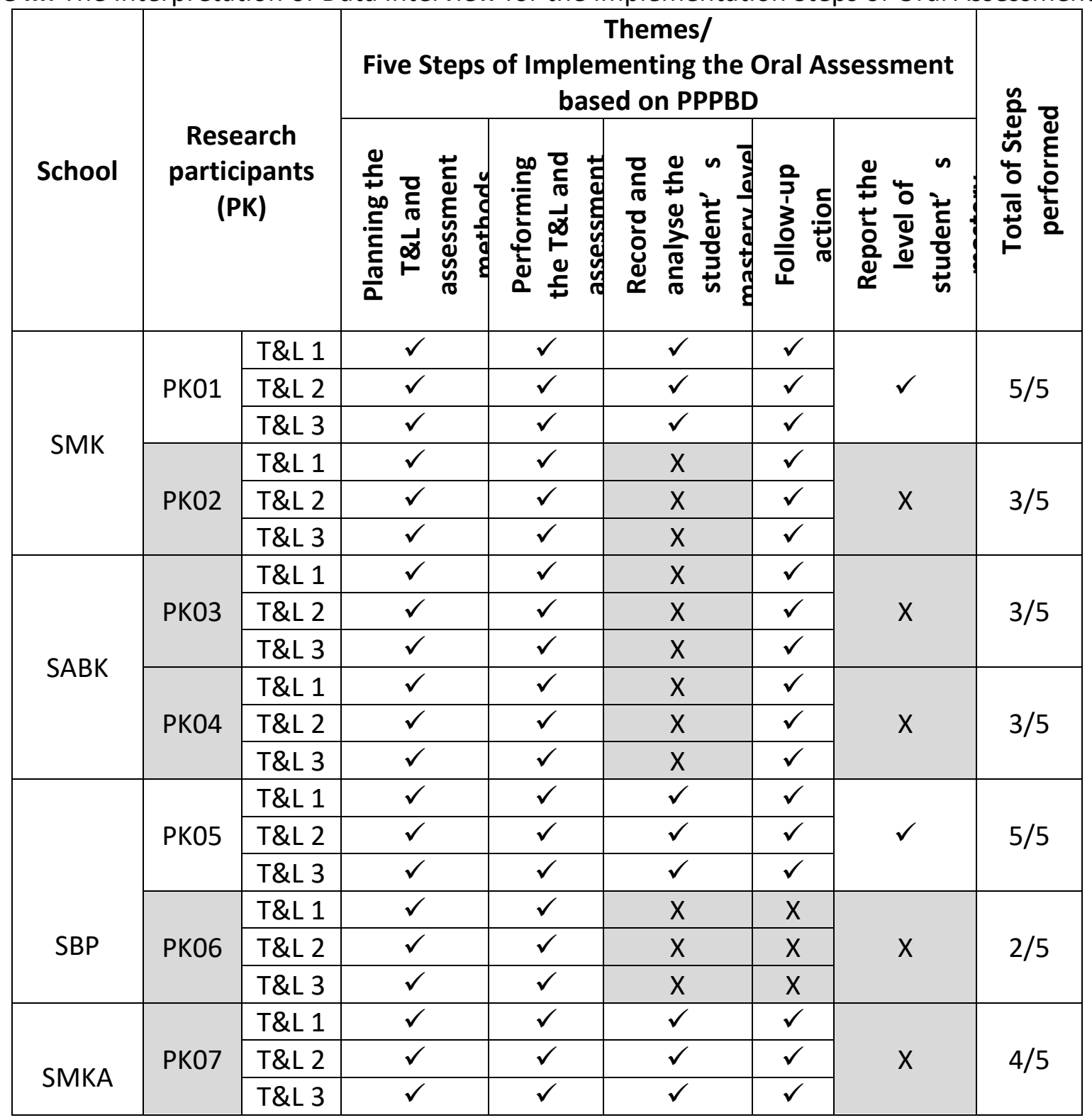

Based on Table III, the analysis of the interviews was conducted on five participants who did not implement any one or two of the measurement methods for oral assessment in the classroom according to PPPBD issued by the Curriculum Development Division (BPK). The study found that three of the participants performed only three steps, namely PK02, PK03, PK04. The three of them did not record or analyse the student's mastery and the effect of that action they did not report the student's mastery level on the day of the observation. When the researcher questioning their attitude during the interview, they stated the following reasons,

PK02: Every time in the class I did not record it on the spot. I will record it after the T\&L. For me, recorded during the class was not suitable because it still in the T\&L period. 
(PK02/TB02/B129)

PK03: As I did before in the transit form that has the student's name and there is a column of the student's highest-level achievement each time the oral assessment is conducted. Usually, we will document the transit form along with other information and normally that is the mark I will give for the 3 levels. Only the highest score I will record later in the PBS data.

(PK03/TB02/B87)

PK04: Supposedly, every time we do the implementation, we should have a transit form. Record it every time we do that. But sometimes I did not bring it. But I told each of the students to write down each SP in every learning occur that day what kind of SP is it. So, from there we know that our students have all done it. Huh. that's it. Because if I want to bring the form, sometimes I do not bring it. Not bring it. So, my evidence is in the student's book.

(PK04/TB02/B40).

The study found that only one participant performed two out of five steps, namely PK06. From his interview, PKO6 informed, he recorded the student's level of mastery based on the availability of time. For example, in one T\&L, the students involved only consist of two to three groups at one time while the other groups will be assessed in the next T\&L. From the researcher's observation, they found that PKO6 will do the recording after the T\&L period because there is not enough time as per his statement,

PK06: Yes, after the T\&L and it took a few days as well. Evaluate individually even though they are stretched in a Group.

(PK06/TB03/B04).

Based on the observations, interviews, and document analysis to all participants, the researchers concluded the analysis of the findings related to the implementation of the Malay language oral assessment as shown in Table IV. 
INTERNATIONAL JOURNAL OF ACADEMIC RESEARCH IN PROGRESSIVE EDUCATION AND DEVELOPMENT

Vol. 10, No. 2, 2021, E-ISSN: 2226-6348 @ 2021 HRMARS

Table IV: The Interpretation of Observational Analysis for the Implementation of Teacher Oral Assessment in the Classroom

\begin{tabular}{|c|c|c|c|c|c|c|c|c|}
\hline \multirow{2}{*}{ No } & \multirow{2}{*}{$\begin{array}{l}\text { Themes/ } \\
\text { The implementation of the Oral } \\
\text { Assessment is carried out in a; }\end{array}$} & \multicolumn{7}{|c|}{ Research Participants (PK) } \\
\hline & & $\begin{array}{c}\text { PKO } \\
1\end{array}$ & $\begin{array}{c}\text { PKO } \\
2\end{array}$ & $\begin{array}{c}\text { PKO } \\
3\end{array}$ & $\begin{array}{c}\text { PKO } \\
4\end{array}$ & $\begin{array}{c}\text { PKO } \\
5\end{array}$ & $\begin{array}{c}\text { PKO } \\
6\end{array}$ & $\begin{array}{c}\text { PKO } \\
7\end{array}$ \\
\hline 1 & Planned & $\checkmark$ & $\checkmark$ & $\checkmark$ & $\checkmark$ & $\checkmark$ & $\checkmark$ & $\checkmark$ \\
\hline 2 & Flexible & $\checkmark$ & $\checkmark$ & $\checkmark$ & $\checkmark$ & $\checkmark$ & $\checkmark$ & $\checkmark$ \\
\hline 3 & Various assessment methods & $\checkmark$ & $\checkmark$ & $\checkmark$ & $\checkmark$ & $\checkmark$ & $\checkmark$ & $\checkmark$ \\
\hline 4 & $\begin{array}{l}\text { According to the suitability of the } \\
\text { student. }\end{array}$ & $\checkmark$ & $\checkmark$ & $\checkmark$ & $\checkmark$ & $\checkmark$ & $\checkmark$ & $\checkmark$ \\
\hline 5 & $\begin{array}{l}\text { According to the readiness of the } \\
\text { student. }\end{array}$ & $\checkmark$ & $\checkmark$ & $\checkmark$ & $\checkmark$ & $\checkmark$ & $\checkmark$ & $\checkmark$ \\
\hline 6 & Based on the curriculum standards. & $\checkmark$ & $\checkmark$ & $\checkmark$ & $\checkmark$ & $\checkmark$ & $\checkmark$ & $\checkmark$ \\
\hline 7 & Continuous. & $\checkmark$ & $\checkmark$ & $\checkmark$ & $\checkmark$ & $\checkmark$ & $\checkmark$ & $\checkmark$ \\
\hline 8 & Formal only. & & $\checkmark$ & & $\checkmark$ & $\checkmark$ & & $/ \checkmark$ \\
\hline 9 & Informal only. & & & & & & & \\
\hline 10 & Formal and informal. & $\checkmark$ & & $\checkmark$ & & & $\checkmark$ & \\
\hline 11 & Problem-solving techniques. & $\checkmark$ & $\checkmark$ & $\checkmark$ & & $\checkmark$ & $\checkmark$ & $\checkmark$ \\
\hline 12 & Learning outside the classroom. & $\checkmark$ & $\checkmark$ & $\checkmark$ & & & & \\
\hline 13 & Student-centered learning. & $\checkmark$ & $\checkmark$ & $\checkmark$ & $\checkmark$ & $\checkmark$ & $\checkmark$ & $\checkmark$ \\
\hline 14 & Thematic approach. & $\checkmark$ & $\checkmark$ & $\checkmark$ & $\checkmark$ & $\checkmark$ & $\checkmark$ & $\checkmark$ \\
\hline 15 & Summative only. & & & & & & & \\
\hline 16 & Formative only. & $\checkmark$ & $\checkmark$ & $\checkmark$ & $\checkmark$ & $\checkmark$ & $\checkmark$ & $\checkmark$ \\
\hline 17 & $\begin{array}{l}\text { Along with the T\&L in the } \\
\text { classroom. }\end{array}$ & $\checkmark$ & $\checkmark$ & $\checkmark$ & $\checkmark$ & $\checkmark$ & $\checkmark$ & $\checkmark$ \\
\hline 18 & Summative and formatively. & & & & & & & \\
\hline 19 & $\begin{array}{l}\text { At the beginning of the learning } \\
\text { unit. }\end{array}$ & & & & & & & \\
\hline 20 & In the middle of the learning unit. & & & & & & & \\
\hline 21 & At the end of the learning unit. & & & & & & & \\
\hline 22 & Throughout the T\&L & $\checkmark$ & $\checkmark$ & $\checkmark$ & $\checkmark$ & $\checkmark$ & $\checkmark$ & $\checkmark$ \\
\hline 23 & Planned the student's assessments. & $\checkmark$ & $\checkmark$ & $\checkmark$ & $\checkmark$ & $\checkmark$ & $\checkmark$ & $\checkmark$ \\
\hline 24 & Build an item for the students. & $\checkmark$ & $\checkmark$ & $\checkmark$ & $\checkmark$ & $\checkmark$ & $\checkmark$ & $\checkmark$ \\
\hline 25 & $\begin{array}{l}\text { Administer the student's } \\
\text { assessments. }\end{array}$ & $\checkmark$ & $\checkmark$ & $\checkmark$ & $\checkmark$ & $\checkmark$ & $\checkmark$ & $\checkmark$ \\
\hline 26 & $\begin{array}{l}\text { Check the student's written answer } \\
\text { script. }\end{array}$ & $\checkmark$ & & $\checkmark$ & & $\checkmark$ & $\checkmark$ & $\checkmark$ \\
\hline 27 & $\begin{array}{l}\text { Recorded the student's } \\
\text { achievement. }\end{array}$ & $\checkmark$ & $\checkmark$ & $\checkmark$ & $\checkmark$ & $\checkmark$ & $\checkmark$ & $\checkmark$ \\
\hline 28 & $\begin{array}{l}\text { Plan the follow-up actions to } \\
\text { improve the students' verbal skills. }\end{array}$ & $\checkmark$ & $\checkmark$ & $\checkmark$ & & $\checkmark$ & $\checkmark$ & $\checkmark$ \\
\hline
\end{tabular}


Vol. 10, No. 2, 2021, E-ISSN: 2226-6348 @ 2021 HRMARS

\begin{tabular}{|c|l|c|c|c|c|c|c|c|}
\hline 29 & $\begin{array}{l}\text { Aims to develop the student's } \\
\text { potential. }\end{array}$ & $\checkmark$ & $\checkmark$ & $\checkmark$ & & $\checkmark$ & $\checkmark$ & $\checkmark$ \\
\hline 30 & $\begin{array}{l}\text { Provide overall information to the } \\
\text { students regarding their knowledge } \\
\text { achievement. }\end{array}$ & $\checkmark$ & $\checkmark$ & $\checkmark$ & & $\checkmark$ & $\checkmark$ & $\checkmark$ \\
\hline 31 & $\begin{array}{l}\text { Provide overall information to the } \\
\text { students about their oral skills. }\end{array}$ & $\checkmark$ & $\checkmark$ & $\checkmark$ & & $\checkmark$ & $\checkmark$ & $\checkmark$ \\
\hline & $\begin{array}{c}24 / 3 \\
1\end{array}$ & $\begin{array}{c}23 / 3 \\
1\end{array}$ & $\begin{array}{c}24 / 3 \\
1\end{array}$ & $\begin{array}{c}17 / 3 \\
1\end{array}$ & $\begin{array}{c}23 / 3 \\
1\end{array}$ & $\begin{array}{c}23 / 3 \\
1\end{array}$ & $\begin{array}{c}23 / 3 \\
1\end{array}$ \\
\hline
\end{tabular}

DSKP and PPPBD stipulate that an assessment includes the items listed in Table IV above. The table above shows that the participant's understanding of the implementation of oral assessment in general. All participants performed formal and informal oral assessments either in the classroom or outside the classroom. The findings of this study prove that the implementation of the assessment carried out by the seven participants took place throughout the T\&L process for an hour or one hour and a half. None of the participants chose to conduct the assessment at the beginning, middle, or end of the learning unit. The selection of various assessment methods by the participants has stimulated the thinking of students to interact in the classroom according to the ability and readiness of the students being assessed. In addition, the analysis of the findings proved that PKO1 and PKO3 showed the highest understanding related to the implementation of oral assessment. While PKO4 only complies with a small amount as outlined in the DSKP and PPPBD when conducting the assessment. This is because, PK04 are lacks of knowledge, training, and skills to conduct the assessments.

PK04: .... because like I said, I'm not really understood the DSKP so, I only use all the materials in the textbook to help me carry out an assessment activity in the classroom. Ermm ... for me, almost all the SPs that I implemented, I used a textbook as a method for me to implement all the SP in the DSKP.

\section{Objective 2}

Formulate the scoring method of student's proficiency level during the oral assessment

The findings are the result of interviews, P's observation, and document analysis covering the Performance Standard of Malay language for form one and form two according to which level the participants teach and the recording forms for seven research participants. In this study, five participants (PK01, PK02, PK03, PK06, and PK07) teach form one students, and another two participants (PKO4 and PK05) teach for form two students. The researchers will explain the participant's understanding of oral assessment scoring based on the three themes developed from the research findings, which the Mastery Level rubric, evaluation by professional judgement, and individual assessment as outlined in PPPBD. 
INTERNATIONAL JOURNAL OF ACADEMIC RESEARCH IN PROGRESSIVE EDUCATION AND DEVELOPMENT

Vol. 10, No. 2, 2021, E-ISSN: 2226-6348 @ 2021 HRMARS

Table V: The Interpretation of Document Analysis for the Scoring methods of Student's Proficiency Level During the Oral Assessment

\begin{tabular}{|c|c|c|c|c|c|c|c|c|}
\hline \multirow[b]{2}{*}{ No. } & \multirow{2}{*}{$\begin{array}{l}\text { Theme/ } \\
\text { Determining methods for the } \\
\text { Oral Assessment Scoring }\end{array}$} & \multicolumn{7}{|c|}{ Research Participants (PK) } \\
\hline & & РK01 & PK02 & РК03 & РК04 & РК05 & РК06 & PK07 \\
\hline 1 & $\begin{array}{l}\text { The mastery of benchmarks is } \\
\text { arranged hierarchically. }\end{array}$ & $\checkmark$ & $\checkmark$ & $\checkmark$ & $\checkmark$ & $\checkmark$ & $\checkmark$ & $\checkmark$ \\
\hline 2 & $\begin{array}{l}\text { The Individual reporting is } \\
\text { based on the standard groups. }\end{array}$ & $\checkmark$ & $x$ & $x$ & $\mathrm{X}$ & $\checkmark$ & $\checkmark$ & $\checkmark$ \\
\hline 3 & $\begin{array}{l}\text { The overall level of mastery of } \\
\text { language skills is determined } \\
\text { by the professional judgment } \\
\text { of the teacher. }\end{array}$ & $\checkmark$ & $\checkmark$ & $\checkmark$ & $\checkmark$ & $\checkmark$ & $\checkmark$ & $\checkmark$ \\
\hline 4 & $\begin{array}{l}\text { The overall level of mastery of } \\
\text { the language skills is } \\
\text { determined at the discretion } \\
\text { of the teacher. }\end{array}$ & $\checkmark$ & $\checkmark$ & $\checkmark$ & $\checkmark$ & $\checkmark$ & $\checkmark$ & $\checkmark$ \\
\hline 5 & $\begin{array}{l}\text { The overall level of mastery of } \\
\text { the language skills is } \\
\text { determined through a variety } \\
\text { of methods. }\end{array}$ & $\checkmark$ & $\checkmark$ & $\checkmark$ & $\checkmark$ & $\checkmark$ & $\checkmark$ & $\checkmark$ \\
\hline 6 & $\begin{array}{l}\text { The language skills are } \\
\text { determined through } \\
\text { observational methods. }\end{array}$ & $\checkmark$ & $\checkmark$ & $\checkmark$ & $\checkmark$ & $\checkmark$ & $\checkmark$ & $\checkmark$ \\
\hline 7 & $\begin{array}{l}\text { The language skills are } \\
\text { determined through the } \\
\text { training methods. }\end{array}$ & $\checkmark$ & $\checkmark$ & $\checkmark$ & $\checkmark$ & $\checkmark$ & $\checkmark$ & $\checkmark$ \\
\hline 8 & $\begin{array}{l}\text { The language skills are } \\
\text { determined through the } \\
\text { student's response methods. }\end{array}$ & $\checkmark$ & $\checkmark$ & $\checkmark$ & $\checkmark$ & $\checkmark$ & $\checkmark$ & $\checkmark$ \\
\hline 9 & $\begin{array}{l}\text { The students need to be given } \\
\text { guidance. }\end{array}$ & $\checkmark$ & $\checkmark$ & $\checkmark$ & $\checkmark$ & $\checkmark$ & $\checkmark$ & $\checkmark$ \\
\hline 10 & $\begin{array}{l}\text { The students need to be given } \\
\text { reinforcement. }\end{array}$ & $\checkmark$ & $\checkmark$ & $\checkmark$ & $\checkmark$ & $\checkmark$ & $\checkmark$ & $\checkmark$ \\
\hline 11 & $\begin{array}{l}\text { There are six levels of } \\
\text { proficiency in the } \\
\text { Performance Standards of } \\
\text { listening and speaking skills. }\end{array}$ & $\checkmark$ & $\checkmark$ & $\checkmark$ & $\checkmark$ & $\checkmark$ & $\checkmark$ & $\checkmark$ \\
\hline 12 & $\begin{array}{l}\text { There are seven Content } \\
\text { Standards in listening and } \\
\text { speaking skills. }\end{array}$ & $\checkmark$ & $\checkmark$ & $\checkmark$ & $\checkmark$ & $\checkmark$ & $\checkmark$ & $\checkmark$ \\
\hline
\end{tabular}


Vol. 10, No. 2, 2021, E-ISSN: 2226-6348 @ 2021 HRMARS

\begin{tabular}{|c|l|c|c|c|c|c|c|c|}
\hline 13 & $\begin{array}{l}\text { Able to distinguish between } \\
\text { Content Standards and } \\
\text { Learning Standards. }\end{array}$ & $\checkmark$ & $\checkmark$ & $\checkmark$ & $\checkmark$ & $\checkmark$ & $\checkmark$ & $\checkmark$ \\
\hline $\begin{array}{l}\text { Learning Standards ensure } \\
\text { that achievement can be } \\
\text { measured by Content } \\
\text { Standards. }\end{array}$ & $\checkmark$ & $\checkmark$ & $\checkmark$ & $\checkmark$ & $\checkmark$ & $\checkmark$ & $\checkmark$ \\
\hline Total & 14 & 13 & 13 & 13 & 14 & 14 & 14 \\
\hline
\end{tabular}

Based on Table $\mathrm{V}$ above, the study's findings clearly show that the determination of oral assessment scoring performed by PK02, PK03, and PKO4 does not follow the guidelines of PPPBD. Giving an average score for the student's achievement is completely wrong and contrary to the guidelines set by the PPPBD. Those actions made by the three participants scoring equally to their students through the group discussion activities were unfair and non-transparent. The scores received by the students should be according to the individual potential rather than given uniformly. This situation shows that the students who deserve to receive follow-up action are not given any opportunity to improve their level of mastery. If this situation is not being addressed, it will negatively impact the student's oral communication in the future. In such cases, PK02, PK03, and PKO4 should be given exposure to the importance of making assessments to the students individually rather than taking an average score.

PK02: If evaluate individually, I will ask a divided question. If it's a group I will ask a representative to speak or answer the question and the rest will get the same marks. Because the representative answer comes from the idea of every member in the groups. The scoring is the same except for a certain student who from the beginning we already know his temperament.

(PK02/TB03/B54)

PK03: Okay, I prefer group work. When a group can perform a task really well that means there shows good cooperation between the group members. Therefore, if I get the best results from them, I will give them a high mark. I give an average score to each member of the group and it's an equal mark.

(PK03/TB01/B200).

PK04: Like I said, to me if some of them can answer that ... it's considered as a lump sum. Average for all of them. Meaning when he can answer and his friends can share their ideas, indirectly I considered his friends to understand it. So, that's the way I assess that they can almost understand and can answer the questions. That means it can go beyond verbal.

(PK04/T\&L02/B18) 
Overall, the analysis of this study proved that the participants understood and complied with the provisions of PPPBD. Nevertheless, it is undeniable that performing the oral assessment from the initial to the final steps in the PPPBD could not be met by all the research participants. For example, recording assessments in the classroom could not be done by most participants due to the limited T\&L time, which was between an hour or one hour and a half. In addition, the large number of students limited the participants to make a record. Therefore, proactive measures need to be formulated and planned systematically so that the oral assessment can be conducted more effectively and by the guidelines of PPPBD. If ignored this matter, the KSSM's desire to produce students who can master the oral language skills while interacting will not be achieved.

\section{Discussion and Recommendation}

Communication and interaction processes are interrelated as the key objectives in verbal skills (Martínez, 2018). Communication in the classroom takes place during the T\&L process aimed at obtaining input from the teachers, students, and learning materials. The students need to understand the assignment given by the teacher and get involved by delivering it in oral form. In this case, Allwright and Baily (1991), Majid (2011) stressed that the teachers must master and understand that the verbal interaction process is fundamental in verbal skills. The students need to play their role in speaking with each other, such as speakers and listeners by responding to what they heard. While the teachers need to understand the meaning spoken. The findings of the research prove that the participants only understand the basics things which is the oral assessment is an interaction that occurs between each of the students, the students with the teachers, and the students with learning materials. A teacher who performs the oral assessment on their students' needs to understand the goal of the oral assessment conducted in line with DSKP (MoE, 2016), which is to produce a student who has a proficient in the language and able to communicate in public, increase the knowledge, improve the oral skills, convey an idea with full of confidence, and practicing social relationships with peers in daily life. The teachers should provide encouragement and guidance so that the students can present their work by giving thoughtful arguments during the oral assessment. The students need to be reminded how important communication is. So, whatever intention is they can successfully convey it and the listener can understand it clearly. Martínez 2018, stated that the teachers need to choose more activities that can allow the students to talk more about their task given.

Winke (2012); Lazaraton (2014) argue that verbal assessment scoring is a difficult process compared with writing skills, particularly in determining its reliability compared to the other four language skills. He stressed that the teachers need to be given guidance, training, and monitored by the stakeholders to measure the scoring accurately and reliably. The findings of Suseela \& Sim (2010); LPM (2012) also prove that the teachers need additional training continuously to strengthen, and improvements can be implemented to lead the assessment system effectively as outlined in DSKP and PPPBD. As an administrator of assessment in the classroom, the participants should be given a depth of knowledge and continuous professional training from time to time to get exposure to the implementation of the assessment methods of the effective oral Malay language. Therefore, the concern from the stakeholders by providing courses or training regularly to the participants will help them make scoring based on the DSKP guidelines, 
Vol. 10, No. 2, 2021, E-ISSN: 2226-6348 @ 2021 HRMARS

and giving scoring based on their perception and understanding can be overcome in the future. All parties need to mobilize energy and take action aggressively so that the fairness of scoring to students is not neglected and it can be addressed immediately. For teachers who are not serious about the implementation of assessment by thinking that they do the implementation only to meet the requirements of the curriculum, they should be given awareness so that the assessment system is not taken lightly as intended by PPPM 2013 to 2025 KSSM.

Throughout this research, the factor that interfered with the smooth implementation of oral assessments is time constraints due to insufficient teaching hours. So, it is not surprising that some of the participants could not assess all the students individually, and the participants did not carry out even follow-up action. The findings of this research support the studies by Suseela \& Sim (2010); Kağan Búyúkkarcı (2014); LPM (2015); Wan Omar (2019). Their study also proved that insufficient time due to many students and the heavy non-academic workload resulted in a neglected focus on assessment. This research also supports the study conducted by Zamri, \& Nor, (2011) proved that a large number of students also causes the teachers not to perform reassessment when the students still have not mastered the skill.

From the aspect of scoring, based on PPPBD, the scoring report aims to see the weaknesses and strengths of a student and a follow-up action so that the improvement of oral skills and T\&L can be done in the future. The scoring emphasizes overall assessment feedback about a student's self that enables the teachers to recognize, understand, appreciate, acknowledge, and glorify them according to their abilities and capabilities. Five participants (PK01, PK02, PK03, PK06, and PK07) teach form one student, and two participants (PK04 and PK05) taught form two students in this study. The researcher will explain the participant's understanding of the oral assessment scoring based on three themes developed from the study's findings: the Mastery Level rubric, assessment by professional judgment, and individual assessment as outlined in the PPPBD. Overall, the analysis of the findings showed that some of the teachers did not meet the standard requirement when given oral assessment scores. The participants still not be able to implement the actual oral assessment due to their diverse understanding of given scoring to the assessed students.

This situation certainly creates a complication in determining the validity of the verbal assessment results received by the student. On the other hand, if viewed from the aspect of assessment practice, the participants proved that they encourage the students on the learning process and create a stimulating learning environment for students to interact. These findings also support the study of Shaari, \& Din (2013); Harun, \& Hamid (2014). They stated that a variety of communicative activities provide opportunities and encouragement for the students to be actively involved and improve their speaking ability when interacting with peers and teachers. Like the study by Zamri, \& Nor (2011), the converse strategy with teachers and some help from peers when practiced in the classroom can improve the mastery level of the Malay language among students who are not a native speaker. This indirectly demonstrates the alignment in PBS that requires the teachers to measure the students from cognitive, affective, and psychomotor (MoE, 2012). The findings of this research are parallel with the study of Fletcher \& Shaw (2012), 
Vol. 10, No. 2, 2021, E-ISSN: $2226-6348$ @ 2021 HRMARS

which showed that the student-directed assessment produces a high score while increasing their motivation and enjoyment of learning compared to teacher-directed assessment. Therefore, the implementation and determination of assessment scores need to be understood and mastered by every teacher to implement oral assessment in a conducive climate and achieve its objectives.

\section{Summary}

The changes in the education system which including the new curriculum, and implementing an assessment in the schools have required the Malay language's teacher to understand its implementation and proper scoring. Teachers as assessors need to ensure that their role in conducting the assessment is clear and follows the correct procedures to produce excellent mankind for the country. The teachers require a lot of time to adapt and complete mastery in the assessment practices. The findings obtained from this study will provide input to various parties, especially the MoE, to ensure the implementation of assessment among the teachers in the schools are transparent and has high reliability. The findings of this study are expected to benefit all parties, especially in education that focuses on classroom assessment.

\section{References}

Abu Naim, H., \& Talib, R. (2014). Prosiding daripada INSAN 2014. Seminar Antarabangsa Kelestarian Insan 2014. Batu Pahat, Johor.

Allwright, D., \& Baily, K. M. (1991). Focus on the Language Classroom. Oxford: Oxford University Press.

Angela, S. (2013). Language assessment literacy as self-awareness: Understanding the role of interpretation in assessment and in teacher learning. Language testing, 30, 310-327. Doi: $10.1177 / 0265532213480128$

Ann, L., \& Milbrey, W. M. (1982). Policy Making in Education. The National Society for the Study of Education. University of Chicago Press.

Arsaythamby, V., \& Hashim, A. R (2016). Teori ujian dan pentaksiran pendidikan. Penerbit: Universiti Utara Malaysia Press.

Arsaythamby, V., Hariharan, N. K., \& Ruzlan, M. A. (2015). Teachers' knowledge and readiness towards implementation of school based assessment in secondary schools. Canadian Center of Science and Education. International Educations Studies, 8(11), 193-203.

Assessment Reform Group. (2002). Assessment for learning: 10 principles. Research based principles to guide classroom practice. Diakses dari dari http://www.moe.gov.my/pt3. Diakses 1 April 2016.

Bachman, L. F. (1990). Fundamental Considerations in Language Testing. Oxford: Oxford University Press.

Baranovskaya, T., \& Shaforostova, V. (2017). Assessment and Evaluation Techniques. Journal of Language and Education, 3(2), 30-38.

Brookhart, S. M. (2007). Expanding views abaout formative classroom assessment: A review of the literature dalam J.H. McMillan (Ed.). Formative classroom assessment: Theory into practice (43-62). New York, NY: Teachers College Press.

Cronbach, L. J. (1990). Essential psycholigical testing. New York: Harper and Row. Doi: 10.17323/2411-7390-2017-3-2-30-38 
INTERNATIONAL JOURNAL OF ACADEMIC RESEARCH IN PROGRESSIVE EDUCATION AND

DEVELOPMENT

Vol. 10, No. 2, 2021, E-ISSN: 2226-6348 @ 2021 HRMARS

Ekua, T. A. S. (2016). Assessment, Student Learning and Classroom Practice: A Review. Journal of Education and Practice. 7(21), 1-6. www.iiste.org

Harun, M. A., \& Hamid, Z. (2014). Penerapan Komunikatif Dalam Pengajaran Bahasa Melayu: Kajian Kes Guru Cemerlang. Jurnal Melayu, 13, 18-28.

https://www.aaia.org.uk/content/uploads/2010/06/Assessment-for-Learning-10principles.pdf

Kağan Búyúkkarcı. (2014). Assessment Beliefs and Practices of Language Teachers in Primary Education. International Journal of Instruction, 7.

Kementerian Pendidikan Malaysia. (2013). Pelan Pembangunan Pendidikan Malaysia 2013-2025 (Pendidikan Prasekolah hingga lepas menengah). Putrajaya: Kementerian Pendidikan Malaysia. Putrajaya.

Kementerian Pendidikan Malaysia. (2014). Penataran Pentaksiran Berasaskan Sekolah (PBS). Bahagian Pembangunan Kurikulum, Putrajaya.

Kementerian Pendidikan Malaysia. (2014). Pentaksiran Berasaskan Sekolah dalam Konteks Malaysia (Perspektif Kementerian Pendidikan Malaysia).

Kementerian Pendidikan Malaysia. (2016). Buku Penerangan Kurikulum Standard Sekolah Menengah (KSSM). Bahagian Pembangunan Kurikulum, Putrajaya.

Kementerian Pendidikan Malaysia. (2016). Dokumen Standard Kurikulum dan Pentaksiran Bahasa Melayu Tingkatan 1. Bahagian Pembangunan Kurikulum, Putrajaya.

Kementerian Pendidikan Malaysia. (2016). Kurikulum Standard Sekolah Menengah (KSSM). Bahagian Pembangunan Kurikulum, Putrajaya.

Kementerian Pendidikan Malaysia. (2016). Laporan Tahunan 2015 Pelan Pembangunan Pendidikan Malaysia 2013-2025. Kementerian Pendidikan Malaysia. Putrajaya.

Kementerian Pendidikan Malaysia. (2016). Panduan Pelaksanaan Pentaksiran Sekolah. Bahagian Pembangunan Kurikulum, Putrajaya.

Kementerian Pendidikan Malaysia. (2017). Pelan Hala Tuju Pendidikan Bahasa Melayu 20162025. Kementerian Pendidikan Malaysia. Putrajaya.

Kementerian Pendidikan Malaysia. (2018). Panduan Pelaksanaan Pentaksiran Bilik Darjah. Pusat Perkembangan Kurikulum. Kementerian Pendidikan Malaysia.

Khamidi, M. F. (2015). Laporan Kursus LADAP Penyebaran DSKP KSSR Tahun 6 Negeri Perak Tahun 2015. Sekolah Kebangsaan Ayer Kuning.

Lazaraton, A. (2014). Second Language Speaking. Dalam M. Celce-Murcia, D. Brinton, \& M.A. Snow. (Eds.), Teaching English as a Second or Foreign Language (4th ed.) (ms. 106-120). Boston, MA: National Geographic Learning/Heinle Cengage Learning.

Lembaga Peperiksaan Malaysia. (2010). Penambahbaikan Pelaksanaan UPSR dan PMR. Kementerian Pendidikan Malaysia.

Lembaga Peperiksaan Malaysia. (2011). Pentaksiran Berasaskan Sekolah. Kementerian Pendidikan Malaysia.

Lembaga Peperiksaan Malaysia. (2014). Panduan Pentaksiran Tingkatan 3 (PT3). Diakses dari

Lembaga Peperiksaan Malaysia. (2015). Kajian berkaitan Pentaksiran Berasaskan Sekolah. Kementerian Pendidikan Malaysia: Putrajaya.

Lembaga Peperiksaan Malaysia. (2017). Panduan Pentadbiran Pentaksiran Tingkatan 3 (PT3). Kementerian Pendidikan Malaysia: Putrajaya. 
Lim, H. L., Wun, T. Y., \& Chew, C. M. (2014). Enhancing Malaysian teachers' assessment literacy. International Education Studies, 7(10): 74-82.

Majid, F. M. (2011). School-based assessment in Malaysian schools: The concerns of the English teachers. Journal of US-China Education Review, 8 (10).

Martínez, J. V. (2018). Teaching Speaking in the English Classroom: Teacher Practices In Swedish Upper Secondary School. Bacelor Degree Project. Stockholm University Library.

Martínez, J. V. (2018). Teaching Speaking in the English Classroom: Teacher Practices In Swedish Upper Secondary School. Bacelor Degree Project. Stockholm University Library.

Mei, T. A. (2010). Pentaksiran Berasaskan Sekolah (PBS) di Malaysia. Kesediaan Guru, Isu dan Panduan Pelaksanaan. Gerak Budaya Enterprise, Kuala Lumpur. Tesis Doktor Falsafah. Universiti Kebangsaan Malaysia.

Merriam, S. B. (2009). Qualitative Research and Case Study Applications in Education. San Francisco: Jossey-Bass Publishers.

Mohamed, M., \& Abd. Aziz, M. S. (2018). Juxtaposing the primary school assessment concepts and practices in Singapore and Malaysia. International Journal of Engineering \& Technology, 7(3.21), 552-556.

Na'imah, I. (2011). School based assessment as transformation in educational assessment. Keynote dalam International Seminar On Measurement and Evaluation (ICMEE 4) USM, Pulau Pinang, 9-12 Oktober.

Pelan Pembangunan Pendidikan Malaysia (PPPM). (2013-2025). (Pendidikan Prasekolah hingga lepas Menengah). Putrajaya, Kementerian Pendidikan Malaysia.

Nair, S. G. K., Setia, R., Nor Zaitolakma Abdul Samad, N. Z., Zahri, R. N. H., Luqman, A., Thenmolli Vadeveloo, T., \& Che Ngah, H. (2013). Teachers' knowledge and issues in the implementation of school-based assessment: A Case of Schools in Terengganu. Asian Social Science, 10, 186-194.

Shaari, A. B., \& Din, A. (2013). Pelaksanaan Aktiviti Komunikatif Dalam Pengajaran Bahasa Melayu Sekolah Rendah: Satu Kajian Kes. Jurnal Pendidikan Bahasa Melayu, 3 (2), 64-78.

Vingsle, C. (2014). Formative assessment: Teacher knowledge and skills to make it happen (Licentiate dissertation). Umeâ University, Department of Science and Mathematics Education.

Wan Omar, S. S. H. (2019). Pengetahuan, kemahiran, sikap, dan masalah guru dalam melaksanakan pentaksiran bilik darjah bahasa Melayu di sekolah rendah. Jurnal Pendidikan Bahasa Melayu, 9(1), 56-67.

Winke, P. (2012). Rating Oral Language. The Encyclopedia of Applied Linguistics. 1-7. Doi: 10.1002/9781405198431.wbea10993

Zamri, M., \& Nor, R. L. (2011). Kepelbagaian kaedah penyoalan lisan dalam pengajaran guru bahasa Melayu: Kaedah pemerhatian. Jurnal Pendidikan Bahasa Melayu, 1(1), 51-65.

Zawawi, I., Ab Halim, T., Nik, M. R., Mohd, N. Y., Ala-Uddin, O. (2011). Teknik pengajaran kemahiran bertutur bahasa Arab di SMKA di Malaysia. GEMA Online ${ }^{\mathrm{TM}}$ Journal of Language Studies, 11, 67-82. 